\title{
Types of Love Between People: A Modern Perspective Using A Descriptive Assessment of Survey Research
}

\author{
Phillip D. Clingan
}

\author{
Pierce College, Psychology Department, Washington, U.S.
}

\author{
Corresponding author details: Dr. Phillip D. Clingan; dr.phillipclingan@gmail.com
}

\begin{abstract}
EXCUTIVE SUMMARY
Love is the strong affection a person has towards the other person. Love can be between people of different gender, age, colour, social status, religion, or nationality. True love knows no boundaries, and that is why there exist different types of love. Most of the different types of love are derived from ancient Greek. The purpose of the study is to show why different people will have a different kind of love and why each of the love is important to the parties involved. The love between two people can take different forms, and two parties cannot have all the ten types of love discussed. The ten types of love discussed include love for parents, love for friends, agape love, love for animals, intimate love, selfish love, and unenduring love for friends, love for close friends, obsessive love towards people, and child love. Each of the love is unique in its way and is beneficial to both parties involved. The greatest of these types of love is agape love. A good example of agape love was portrayed in the life of Jesus in the Bible. He loved the human race unconditionally and gave all to save them from humanity. Also, child love and parent love are important types of love because they enhance strong bonds between parents and their children. Animal love can be obsessive because it will make a person become too close to animals in caring for them. However, it's an important type of love because it creates a good relationship between human beings and animals. Animals tend to feel protected in the presence of human beings.
\end{abstract}

Keywords: types of love; modern perspective; love between people

\section{INTRODUCTION}

Love is defined as a strong affection towards a person or something. Love can include a sexual desire for a person you have a romantic relationship with. In most cases, love comes naturally, and it's not something that a person will force to the other. People express love to other people in different ways, including sending gifts, through acts of service, words of affirmation, physical touch, or through the quality time you spend with a person. The love language that people have towards each other should be the same because if two people have different love languages, it may be the source of problems in that love relationship. The issues that arise in love relationships come as a result of a misunderstanding between the two people involved. It calls for commitment, hard work, and understanding to make a long-lasting relationship (Morgan, 2020).

Thesis statement: The ancient Greek-derived some ten different types of love, including agape love, love for animals, love for parents, child love, enduring love, intimate love, obsessive love towards people, selfish love, love for a friend, and love for close friends. The study will focus on discussing the different types of love, and the most important type of love and why it's important.

\section{Problem Statement}

After being in love for the first time or experiencing even the mildest form of a type of love whither than be of a parent, an animal, a friend or a lover, the idea of love is changed forever. The person then needs to decide based on their types of love life experience to accept love and embrace Love to fulfill themselves in life as a person. Not all types of love benefit a person throughout life as each life experience of the different types of love differ for each person. The person must decide how to embrace the types of love throughout life. In this experiment, I will investigate the types of love, educate the participants then issue a survey tool to establish a modern perspective of how people of ages between 18-35 perceive love.

\section{Objective Statement}

The purpose of the study is to define the different types of love. The study will focus on ten main types of love that are common in a relationship that people build amongst each other. Love is everywhere, and it's something that comes naturally, and usually, every person will have one or more types of love. A person will have to fall in love at one point in life. People build love relationships at home, school, and in the community, but they rarely understand the kind of relationship they have. Also, in most cases, people tend to confuse the different types of love, giving a wrong explanation, for example, to a kind of love that was not supposed to be. It will discuss why it's important for a person to have the specific type of love that he or she will have and how to improve on the existing love.

\section{LITERATURE REVIEW}

\section{Agape love}

The first and most important type of love is agape or unconditional love. Agape love is one of its kind, and only a few persons will have this specific type of love. It calls for loving, unconditional love without expecting anything in return from the people you show love. 
It calls for a person to love compassionately and sacrifice for the sake of those he or she loves. Agape love can be defined as infinite passion and boundless empathy. It's a kind of love that has a love for everyone and everything around (Smith, 2019). In the presence of agape love, it leaves people with a sense of happiness and peace.

A person with an agape type of love will be more concerned about touching the lives of people. He or she will interact with the lowly or despised people in society. Agape or selfless love knows no boundaries. People with agape kind of love will not expect a gift or returns for loving or doing well to someone. A good example of agape love is portrayed in the life of Jesus in the Bible. Jesus loved all people and interacted with them without limits. He did not mind their class, social status, or nationality. He should compassionate to the sick and went ahead to touch their lives. In most instances, Jesus suffered for the happiness of others. Jesus died for the sins of all men to set them free. He did not expect any returns from human beings for the sacrifice he made for their lives. Therefore, agape love is one of the unique types of love that people can have. It's a kind of love that calls for a selfless being to portray this kind of love to others.

\section{Love for parents}

Love for parents is another special type of love. It's a kind of love depicted between parents and children. A parent might have a special kind of love with her son or daughter, depending on the special relationship they have. Parentchild love comes naturally, and a parent cannot be forced to love his or her daughter. They relate well and share mutual trust between each other (Burton, 2016). It brings a sense of closeness and affection, whereby a parent of the child will keep on checking the whereabouts of the other. It promotes a sense of wellbeing and belonging in a family.

\section{Love for a friend}

Friend love comes in the form of Philia love between two or more people. It's that kind of love that a person gave strong feelings towards friends. Philia love is better than other types of love because it represents the love between people who consider themselves as equal. In philia love, no party is considered better or superior to the other because they view themselves as equal (Burton, 2016). This kind of love does not necessarily have sexual acts or sexual desires between the two people in love. It can be a love relationship between a male and a female or people of the same sex. Philia love builds s strong friendship that is founded on goodness, and it's not only associated with mutual benefits but also trust and dependability. True friends will love to seek to live together and true to each other regardless of their differences. It's through philia love that one will find a friend who is open and straight in his or her actions.

\section{Philautia or self-love}

Philautia love is the kind of love that a person has for himself or herself. Self-love comes with high self-esteem or healthy love towards self. In life, everyone is expected to have some level of self-love because one cannot love others if he or she cannot love self. Self-love or philautia is portrayed by the way we feel, act, or think about ourselves and other people (Kaladharan, 2017). When self-love is cultivated, it brings about self-confidence in us and others. In terms of the relationship between two people, philautia love advocates loving the other person just as you love yourself. It's expected that a person will show the same level of affection as he or she has to self. If a person does not love themselves, then it becomes difficult to love the other person. Philautia love makes a person to be open for growth and develop a fulfilling relationship with others. Self-love aims to beautify things and make good things out of it to self and others.
Love for close friends also known as Storge Love

Storge is also referred to as familial love. It's a kind of love that a person has close affectionate to other friends. It is more related to philia love. This kind of love is more common among parents and their children. It's the parentchild love, the love that a parent has towards his or her child and vice versa. There is a strong bond, familiarity or kinship between people in this kind of love. Storge love creates strong ties even if people are far away from each other; there will be assured of love from their parents or children (Kim, 2004). When people are in a relationship, they will also expect storge love, the feeling of dependency on the other person. Therefore, storge love is an excellent example of the kind of love that parents should have towards their children. It creates a sense of belonging to children and their parents.

\section{Love for animals}

Love for animals is another type of love that exists between people and animals. Mostly, its people who portray their love towards animals. For instance, a person might show love to pets. Love for animals comes through caring for animals at any cost. One will feel comfortable when they are around animals, and they will care and keep animals in better condition as human beings. Love for animals drives a person to frequently visit the animal orphanage, zoos, and animal dens to interact with animals. Only a few people can understand how to care for animals, and this comes as a result of interest and spending time with animals to learn their behaviors.

\section{An enduring love for friends}

Pragma love is also known as enduring love. It's a good example of the kind of love that two people in love should have. It endures happiness, sickness, and bad days that parties in a relationship will have. Pragma love does not require much effort from each other because both people are good at honoring their promises. People with pragma love can preserve and withstand each other's weaknesses. Each party in that love will make efforts to see the other person happy (Kim, 2004). An excellent example of pragma or enduring love is depicted in old couples who have lived together from their teenage old to old age, and they still love each other. It shows that each person has endured and tolerated the other one despite the differences. Pragma love has matured with over a period. Pragma love between two people will need a lot of patient and hard work from both parties. However, this kind of love is rare to find, especially in the current society.

\section{Obsessive love towards a person or things}

Mania love is also referred to as obsessive love. Mania's love is common between two people in love. However, it can be a destructive love because one partner is usually obsessive or too much attached to the other person. In most cases, one party in this kind of love will want to be respected and will force love as a way of reinforcing the self-respect they desire (Princess, 2010). Mania's love can lead one partner to be jealous and over possessive about the other person. In case one partner fails to love the way the other person is loving, it can result in problems. However, two people under this kind of love can suffer from low self-confidence and low self-esteem. The reason is that a person will always be at the fear of losing their partner. In case one partner loses control, mania love can be destructive.

\section{Intimate love}

Intimate love is love that is characterized by sexual desire towards another person. Intimate love is common among people in relationships, couples and married persons. Intimate love is mostly for the opposite sex, male and female. When people have intimate love, they show sexual 
desire towards the other partner (Raffagnino \& Puddu, 2018). They will act in a way they portray sexual desires and feelings. Under intimate love, each party will show mutual love towards each other. They tend to have mutual understanding and feelings (Kaladharan, 2017). The bond between people with intimate love is strong, and they normally solve out their differences with love and understanding. People with intimate love are faithful and determined to make the other person happy. They always present gifts and presents for their love partner. They also appreciate each other because they have a mutual understanding.

\section{Love for a child (child love)}

Apart from parent love, there is also a child love. Every parent will have some special kind of love for their children. A child loves due to paternal or maternal relationship. A parent will not love a child who is not his or hers the same way he will love his child. The child love comes through numerous sacrifices. For instance, a parent will sacrifice to ensure the child gets the best (Smith 2019). A parent will sacrifice to see the child get a good education, better healthcare, and a good future. If a child asks for anything, a parent will rush to provide to the child. There is a blood connection that makes a parent more responsible for her child more than other people. Child love makes parents be responsible and be determined to bring up a respected and morally upright child.

\section{Analysis of Literature}

The love between two people can be different depending on the relationship the two people have. A person can love his or her child unconditionally in the complete sense of love. A person can love a friend or parent in a different way depending on the relationship. People tend to show compassion and love for others. Understanding is the key to building all ten types of relationships mentioned above. When misunderstanding crops into a relationship because of the beginning of problems, which can end up breaking the love relationship that ever existed. Love languages must be the "centre" of each love relationship that aims to grow and move to greater heights. There is a need to give gifts, say a word of affirmation like 'I love you' or act nicely to other people. Spending quality time with the loved one and extending a physical touch is also love languages that keep the love relationship moving and functional. Each type of love mentioned above needs to be nurtured and treated with dignity. If two people in a relationship fail to respect each other, there is a likelihood of failing in their relationship (Neto, \& Wilks, 2017). Therefore, it's essential to know and understand the kind of relationship that you have developed over time and understand ways to build and improve the relationship.

\section{TYPES OF LOVE}

In the English language the word "love" covers a range of emotions and relationships. There is the love between friends, between family members, and between animals and their keepers. There is also the love of heterosexual and homosexual relationships, where physical sex is often a component. The confusion between types of love is more profound in English than in Greek, where there are at least six words for love:

Agape: The love between man and god. It can also be love directed towards humanity, or the love within a family, community, or church.

Eros: Love relating to attraction, passion, and sex.

Philia: The love between friends, involving equality and loyalty.

Storgia: Love between parents and children. Or perhaps for one's country, clan or team.

Philautia: Love for oneself.

Xenia: Love for the people who receive one's hospitality.
The host-guest relationship.

The present study looked at the relationship between some of these types of love, by asking participants a range of questions. The study was exploratory in nature, and the answers to the questions, and their inter-correlation, will help inform future studies.

\section{METHOD}

\section{The Questionnaire}

The questionnaire had six main demographic and lifestyle questions. These were gender, age, race, sexual orientation, age when first fell in love, and number of intimate relationships. The number of intimate relationships was coded through ordinal categories.

The questionnaire had 29 questions and statements relating to attitudes towards love. The responses to these questions and statements did not have a uniform format. One question had a 9-point Likert scale:

- How long does it take to fall in love?

Four questions had a yes/no format:

- Do you believe in love at first sight?

- Do soul mates exist?

- Does that special person exist?

- Can I intimately love more than one person at a time?

Nine questions were answered with a numerical rating, between 0 and 100 :

- Do you know love when you see it?

- Love is defined as an intense feeling of deep affection.

- Can the intensity of love be the same with my friend as I have with my lover?

- Does sex differentiate the type of love I have with my friend vs my lover?

- Can I have sex with my friend and still intimately love my partner/husband/wife/lover?

- Is monogamy realistic in a loving relationship?

- Can I have an affair and still love my wife/husband/ partner?

- Is love everlasting?

- Would you leave your partner today for a better love relationship if you could?

Ten questions were answered on a five-point Likert scale:

- I can live a happy life and be in love without marriage.

- Love is important to me as a person.

- Can I intimately love you without sex?

- Pragma love (between friends) endures.

- Mania love can be destructive because of obsession or over-attachment.

- Is love hard to find?

- Have you experienced natural parent-child love?

- Have you ever experienced agape love?

- Do you love your parents?

- Have you ever loved an animal?

Four questions were answered on a four-point Likert scale:

- How important is sex in the love relationship?

- Is it likely that one would experience love for a friend (philia)?

- Have you ever experienced intimate love?

- Is love for one's biological child positive or negative?

One question was answered on a three-point Likert scale: - Do you love yourself (philautia)?

\section{Data analysis}

The first part of the study focused on correlations and comparisons between different demographics and lifestyle choices. Non-parametric tests were used throughout: Spearman's rho was used for correlations, Mann-Whitney 
for comparisons between two groups, and Kruskal-Wallis for three groups or more. As the study was of an exploratory nature, there were no corrections for multiple comparison. Alpha was set at .05.

The second part of the study consisted of a reliability analysis (Cronbach's alpha) followed by a factor analysis, which involved principal components analysis and a varimax rotation. This was done in full awareness of the probability that the data was unsuitable for factor analysis.

\section{Participants}

The study had 51 participants (22 men, 19 women, $M_{\text {age }}=$ 26.45 , age range: $18-35$ years). Thirty-seven (72.5\%) of the participants were white (Table A1) and 34 (66.7\%) identified as heterosexual (Table A2). The mean age at which participants reported that they had fallen in love for the first time was 17.84 (age range: 12-25). Thirty-three participants $(64.7 \%)$ had experienced one or two love relationships, $17(33.3 \%)$ had experienced three to five, and one had experienced more than 10 .

\section{RESULTS}

\section{Item analysis}

The purpose of a basic item analysis is to check platform and ceiling effects, as well as to check for unusually concentrated responses. Where this happens, there are doubts about the usefulness of the item, in terms of discriminating between participants.

The item "Does that special person exist?", had 44 out of 51 answering in the affirmative (86.3\%). In the items with 0 100 answers, "Love is defined as an intense feeling of deep affection" had the lowest standard deviation (18.69). Other items with relatively low standard deviations were "Love is defined as an intense feeling of deep affection" (.56) and "Pragma love (between friends) endures" (.61).

\section{Missing items}

Four of the 47 participants did not answer the question "Would you leave your partner today for a better love relationship if you could?".

\section{Demographic and lifestyle differences}

Gender. A series of Mann-Whitney tests were performed, with gender as the independent variable. Males and females showed significant differences for the items "Love is important to me as a person" ( $U=175.5, p=.003)$ "Pragma love (between friends) endures" $(U=200.0, p=$ .008), "Mania love can be destructive..." ( $U=212.5, p=$ $.035)$, and "Is love hard to find" ( $U=199.5, p=.016)$ Females had higher mean scores for all four items (See Table A3 below)

TABLE A3: Descriptive statistics for items with significant gender differences.

\section{Group Statistics}

\begin{tabular}{|c|c|c|c|c|c|}
\hline & Gender & $\mathrm{N}$ & Moan. & Stc. Devishon & $\begin{array}{l}\text { S76. Eror } \\
\text { Meant }\end{array}$ \\
\hline \multirow{2}{*}{$\begin{array}{l}\text { Love is important to me } \\
\text { as a person. }\end{array}$} & female & 29 & 4.55 & 686 & 127 \\
\hline & Nale & 22 & 3.86 & 941 & 201 \\
\hline \multirow{2}{*}{$\begin{array}{l}\text { Pragma lose (bistosen } \\
\text { fiends) enduras. }\end{array}$} & Fimalt & 29 & 4.69 & .660 & 123 \\
\hline & Male & 22 & 4.36 & .492 & .105 \\
\hline \multirow{2}{*}{$\begin{array}{l}\text { Uania tove can be } \\
\text { destructie beraves of } \\
\text { obsession or peet } \\
\text { athathment. }\end{array}$} & Female & 29 & 3.59 & 1.211 & 225 \\
\hline & Male & 22 & 2.86 & 1.167 & 249 \\
\hline \multirow[t]{2}{*}{ Is love hard to snd? } & Feniale & 29 & 4.17 & .848 & .157 \\
\hline & Male & 22 & 3.59 & 734 & .157 \\
\hline
\end{tabular}

Age. Participants' age had a significant Spearman's correlation with "Do you know love when you see it?" ( $\rho=$ $.451, p=.001)$, "Is love everlasting?" $(\rho=.279, p=.047)$, "Love is important to me as a person" ( $\rho=.418, p=.002)$
"Have you experienced natural parent-child love?" $(\rho=$ $.278, p=.048)$, "Do you love yourself (philautia)?" $(\rho=.423$, $p=.002)$, "Do you love your parents?" $(\rho=.331, p=.018)$, and "Have you ever experienced intimate love?" $(\rho=.472$, $p<.001)$.

Race. Five Kruskall-Wallis tests showed statistical significance: "Can I have sex with my friend and still intimately love my partner/husband/wife/lover?" $(H(5)=$ 15.38, $p=.009$ ), "I can live a happy life and be in love without marriage" $(H(5)=14.18, p=.014)$, "Do you love your parents?" $(H(5)=12.81, p=.025)$, "Have you ever experienced intimate love?" $(H(5)=14.47, p=.013)$, and "Is love for one's biological child positive or negative?" $(H(5)=12.83, p=.025)$. See Table A2 below for the descriptive statistics. The item with the highest $H$, "Can I have sex with my friend and still intimately love my partner/husband/wife/lover?", had Asians $(M=75)$ and Hispanics $(M=65)$ scoring higher than other races (See Table A1 below).

TABLE A1: Frequencies and percentages for race.

\begin{tabular}{|c|c|c|c|c|c|}
\hline \multicolumn{6}{|c|}{ Descriptives } \\
\hline & & N & Hean & 5td Deviatove & SWo Empr \\
\hline \multirow{7}{*}{ 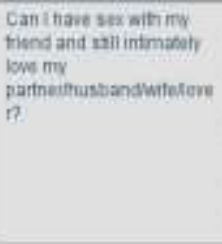 } & Whet & 37 & 26.32 & 29.698 & 4914 \\
\hline & Mtican Nmeritan & 2 & .00 & 500 & .000 \\
\hline & Hisparic & 5 & 55,00 & 20774 & 13,315 \\
\hline & Asian & 3 & 75.00 & 27839 & 15073 \\
\hline & Jiakse American & 1 & 31.00 & & \\
\hline & Mubracial & 3 & 8.00 & 13.566 & 8000 \\
\hline & That & 51 & 30,96 & 32724 & 4582 \\
\hline \multirow{7}{*}{$\begin{array}{l}\text { ICan live a happy ite and } \\
\text { be in live withost } \\
\text { mansge }\end{array}$} & vane & 37 & 4.22 & 787 & 129 \\
\hline & Mracan Arostitan & 2 & 200 & 1414 & 1000 \\
\hline & Hisparif: & 5 & 5.00 & 000 & .000 \\
\hline & Aasian & 3 & 400 & $\infty 00$ & 000 \\
\hline & Matve American & 1 & 5.00 & & \\
\hline & Muniacial & 3. & 4.33 & 577 & .333 \\
\hline & Toas & 51 & 4.22 & 879 & 123 \\
\hline \multirow[t]{7}{*}{ Do you leve yeur parants? } & When & 3t & 4.30 & 1024 & 168 \\
\hline & Ancan Amistican & 2 & 5.00 & 000 & 000 \\
\hline & Hisbavi: & 5 & 260 & 1342 & 600 \\
\hline & Ascan & 3 & 3.39 & 577 & 333 \\
\hline & Hiatie Ameitant & 1 & 4.00 & . & \\
\hline & Munracial & 3 & 433 & 577 & 333 \\
\hline & Tomal & 51 & 4.10 & 1.118 & 157 \\
\hline \multirow{7}{*}{$\begin{array}{l}\text { Hawe vou ever } \\
\text { expechensed intimate } \\
\text { ines? }\end{array}$} & Whine & 37 & 3.46 & 896 & 138 \\
\hline & Mtican Nouritan & 2 & 3.00 & 000 & 000 \\
\hline & Hisparic & 5 & 3.80 & 447 & 200 \\
\hline & Astan & 3 & 2.33 & 577 & 333 \\
\hline & Hahe American & 1 & 4.00 & 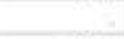 & \\
\hline & Mutiracial & 3 & 1.67 & 1135 & 667 \\
\hline & Treal & 51 & 3.31 & 227 & 130 \\
\hline \multirow{7}{*}{$\begin{array}{l}\text { Is lowe for one y ticlogical } \\
\text { thitu positere or negafine? }\end{array}$} & Whes & 37 & 3.08 & $m 2$ & 119 \\
\hline & Arcandietean & 2 & 200 & 1414 & 1000 \\
\hline & Hisparie & 5 & 2.00 & 707 & 316 \\
\hline & Msian & 3 & 2.33 & 577 & 333 \\
\hline & Natore American & 1 & 1.00 & $=$ & 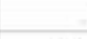 \\
\hline & Mubracial & 3 & 2.00 & 1.000 & .577 \\
\hline & Total & 51 & 2.84 & 857 & 120 \\
\hline
\end{tabular}

Sexual orientation. Two Kruskall-Wallis tests showed statistical significance: "How important is sex in the love relationship?" $(H(5)=11.19, p=.048)$ and "Have you ever loved an animal?" $(H(5)=11.77, p=.038)$. Participants who identified as pansexual and asexual gave the highest rating for "How important is sex in the love relationship?" $(M=4.0)$. Participants who identified as queer, bisexual, and pansexual gave the highest ratings for "Have you ever loved an animal?" $(M=5.0$ ), (See Table A3 and Table A4 below). 
TABLE A3: Frequencies and percentages for sexual orientation.

\begin{tabular}{|c|c|c|c|c|c|}
\hline \multicolumn{6}{|c|}{ Sexual orientation } \\
\hline & & Frequency & Percent: & Valid Percent & $\begin{array}{l}\text { Cumulative } \\
\text { Percent }\end{array}$ \\
\hline \multirow[t]{7}{*}{ Valid } & Heterosexuallstraight & 34 & 66.7 & 66.7 & 66.7 \\
\hline & Queer & 2 & 3.9 & 3.9 & 70.6 \\
\hline & Bisenual & 10 & 19.6 & 19.6 & 902 \\
\hline & Panserual & 2 & 3.9 & 3.9 & 94.1 \\
\hline & Aserual & 1 & 2.0 & 2.0 & 96.1 \\
\hline & Wane of the above & 2 & 3.9 & 3.9 & 1000 \\
\hline & Tota: & 51 & 100.0 & 100.0 & \\
\hline
\end{tabular}

TABLE A4: Descriptive statistics for questions with significant sexual orientation differences.

\begin{tabular}{|c|c|c|c|c|c|}
\hline \multicolumn{6}{|c|}{ Deseriptives } \\
\hline & & N & Naan & 5ta. Destamon & stit Erres \\
\hline \multirow{7}{*}{ 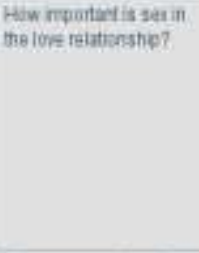 } & Heterogenuilstalyt & 34 & 253 & 780 & 135 \\
\hline & Suept & 2 & 200 & 1414 & 1000 \\
\hline & Bsatual & 10 & 210 & 738 & 233 \\
\hline & Pasuenal & 2 & 400 & 000 & 000 \\
\hline & Asemal & 1 & 4.00 & 1 & 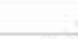 \\
\hline & Nane afline above & 2 & 200 & 900 & 000 \\
\hline & Total & 51 & 249 & 857 & 120 \\
\hline \multirow{7}{*}{$\begin{array}{l}\text { Have yu enes loved an } \\
\text { grimal? }\end{array}$} & Hgleresenuatstrabst & 34 & 1.24 & 1017 & 174 \\
\hline & Ouen & 2 & 500 & 000 & 000 \\
\hline & Bisaval & 10 & 500 & 000 & 000 \\
\hline & Panterual & 2 & 500 & 000 & 000 \\
\hline & Aseual & 1 & 2.00 & $=$ & - \\
\hline & tione afthe above & 2 & 4.50 & 707 & 500 \\
\hline & fótel & 51 & 4.41 & 963 & .135 \\
\hline
\end{tabular}

\section{Attitudes to love}

This section is a list of the results from the items gauging attitudes and feelings about love. They are all correlations and organized by item. Significant correlations are only listed in the sections for one item. If the section for Item A lists a correlation with Item B, this correlation will not be listed in the section for Item B.

How long does it take to fall in love?

- Do you believe in love at first sight? ( $\rho=-.365, p=.008$ )

Do you know love when you see it?

- Does that special person exist? $(\rho=.490, p<.001)$.

- Is love everlasting $(\rho=.410, p=.003)$.

- Love is important to me as a person $(\rho=.624, p<.001)$,

- How important is sex in the love relationship? $(\rho=$ $.291, p=.038$ ).

- Do you love yourself (philautia)? $(\rho=.363, p=.009)$.

- Have you ever experienced intimate love? $(\rho=.330, p$ $=.018$ ).

Do you believe in love at first sight?

- Do soul mates exist? ( $\rho=.388, p=.005)$.

- Does that special person exist? $(\rho=.282, p=.045)$.

- Love is defined as an intense feeling of deep satisfaction? ( $\rho=.281, p=.045)$.

- Mania love can be destructive... $(\rho=.279, p=.047)$.

Do soul mates exist?

- Does that special person exist? $(\rho=.344, p=.013)$.

- Is love everlasting? ( $\rho=.301, p=.032)$.

- Pragma love (between friends) endures ( $\rho=.309, p=$ .027).

Does that special person exist?

- Is love everlasting? ( $\rho=.346, p=.013)$.

- Love is important to me as a person ( $\rho=.317, p=.023)$.
- Pragma love (between friends) endures ( $\rho=.345, p=$ $.013)$.

Love is defined as an intense feeling of deep affection.

- Do you love your parents? ( $\rho=.321, p=.022)$.

- Have you ever loved an animal? ( $\rho=.283, p=.044)$.

Can the intensity of love be the same as I have with my friend as I have with my lover?

- Can I still have sex with my friend and still intimately love my partner...? $(\rho=.480, p<.001)$.

- Can I intimately love more than one person at a time? $(\rho=.477, p<.001)$.

- I can live a happy life and be in love without marriage $(\rho=.276, p<.05)$

- Can I intimately love you without sex? $(\rho=.355, p=$ .011).

- Have you ever loved an animal? ( $\rho=.434, p=.001)$.

Does sex differentiate the type of love I have with my friend vs. my lover?

- Love is important to me as a person $(\rho=.306, p=.029)$.

Can I have sex with my friend and still intimately love my partner...?

- Is monogamy realistic within a loving relationship? $(\rho$ $=-.434, p=.001$ ).

- Can I have an affair and still love my wife...? $(\rho=-.553$, $p<.001$ )

- Would you leave your partner today for a better love relationship if you could ( $\rho=.380, p=.008)$

- Can I intimately love more than one person at a time? $(\rho=.587, p=<.001)$.

- I can live a happy life and be in love without marriage $(\rho=.353, p=.011)$

- Mania love can be destructive... $(\rho=.282, p=.045)$.

- Have you ever experienced agape love? $(\rho=-.346, p=.013)$

Is monogamy realistic within a loving relationship?

- Can I have an affair and still love my wife...? $(\rho=-.401, p=.004)$.

- Would you leave your partner today for a better love relationship if you could $(\rho=.586, p<.001)$

- Can I intimately love more than one person at a time? $(\rho=-.424, p=.002)$.

- I can live a happy life and be in love without marriage $(\rho=-.329, p=.019)$.

- Love is important to me as a person ( $\rho=.320, p=.022)$.

Can I have an affair and still love my wife...?

- Can I intimately love more than one person at a time? $(\rho=.419, p=.002)$.

- I can live a happy life and be in love without marriage $(\rho=.287, p=.041)$

- How important is sex in the love relationship? $(\rho=.291, p=.038)$

Is love everlasting.

- Mania love can be destructive... $(\rho=.290, p=.039)$.

- Do you love yourself (philautia)? $(\rho=.365, p=.008)$.

- Do you love your parents? $(\rho=.307, p=.029)$

Would you leave your partner today...?

- Love is important to me as a person $(\rho=-.436, p=.002)$.

- Can I intimately love you without sex? $(\rho=-.323, p=.027)$.

Can I intimately love more than one person at a time?

- I can live a happy life and be in love without marriage $(\rho=.496, p<.001)$ 
I can live a happy life and be in love without marriage.

- Have you ever loved an animal? $(\rho=.380, p=.006)$.

Love is important to me as a person.

- How important is sex in the love relationship? $(\rho=.311, p=.026)$.

- Have you ever experienced intimate love? $(\rho=.336, p=.016)$.

Can I intimately love you without sex?

- How important is sex in the love relationship? $(\rho=-.438, p=.001)$

- Is it likely that one would experience love for a friend...? $(\rho=.281, p=.046)$.

Pragma love (between friends) endures.

- Mania love can be destructive... $(\rho=.341, p=.014)$.

- Is it likely one would experience love for a friend?

- $(\rho=.291, p=.038)$.

- Have you ever loved an animal? $(\rho=.296, p=.035)$.

Mania love can be destructive...

- Have you ever loved an animal? ( $\rho=.363, p=.009)$.

Is love hard to find?

- Have you ever experienced intimate love? $(\rho=-.348, p=.012)$.

Have you experienced natural parent-child love?

- Do you love your parents? $(\rho=.405, p=.003)$.

Have you ever experienced agape love?

- Is it likely that one would experience love for a friend...? $(\rho=.463, p=.001)$.

Is it likely that one would experience love for a friend...?

- Do you love your parents? ( $\rho=.277, p=.049)$.

Do you love yourself (philautia)?

- Have you ever experienced intimate love? $(\rho=.277, p=.049)$.

Do you love your parents?

- Is love for your biological child positive or negative? $(\rho=.455, p=.001)$.

Factor analysis

The data was unsuitable for a factor analysis. Cronbach's alpha for the 29 attitude questions was .46. The KaiserMeyer-Olkin statistic was .425 , which suggests that the sampling was not adequate. There was also a violation of Barlett's sphericity assumption, $\chi^{2}(406)=584.75, p<.001$. As one item had four missing replies, only 47 participants were included in the analysis.

An analysis indicated that Cronbach's alpha would be improved by the removal of "Does sex differentiate the type of love I have with my friend vs my lover?" and "Is monogamy realistic in a loving relationship". These items were removed, and the age of participants was added. The reason age was added, in spite of it being a demographic variable, was because the answers to some items may be influenced by participants' maturity. These changes increased Cronbach's alpha to .55. The Kaiser-Meyer-Olkin statistic was .438, Barlett's sphericity test $\chi^{2}(378)=$ $554.64, p<.001$.

A principal components analysis showed ten factors with eigenvalues of one or greater, explaining $73.73 \%$ of the variance. The solution was rotated, using varimax (Table A5).
Items with an absolute loading of less than .4 were suppressed from the print-out. Each factor was named, using a description that seemed to best summarize the items that loaded onto it.

Factor 1: Love knows no bounds. "Can the intensity of love be the same with my friend as I have with my lover?" (.679), "Can I have sex with my friend and still intimately love my partner...?" (.690), "Can I have an affair and still love my wife...?" (.567), "Can I intimately love more than one person at a time?" (.751), "I can live a happy live and be in love without marriage" (.748), "Pragma love (between friends) endures" (.504), and "Have you ever loved an animal?" (.581). This factor is love without bounds because it is expansive. It is about the many ways in which one can love, with or without sex. One's love is not constrained by the fact that one is in a relationship, but it is not just about sex - you love friends, you can love an animal.

Factor 2: Love is an ideal, enduring, and healthy state between two people. "Do you know love when you see it?" (.778), "Does that special person exist?" (.695), "Is love everlasting?" (.702), "Love is important to me as a person" (.474), "Mania love can be destructive..." (.490). Factor 2 is about a special relationship between two people, where the love is healthy, natural, and enduring. It is healthy because it is not obsessive or manic - and it is certainly not destructive.

Factor 3: Confident, mature love. "Is love hard to find?" (-.615), "Do you love yourself (philautia)? (.639), "Have you ever experienced intimate love?" (.791), and age (.668). Someone who has high self-regard, who has experienced love, who does not have problems finding it. And with age comes confidence and experience in love.

Factor 4: The importance of sex. "Can I intimately love you without sex?" (-.769) and "How important is sex in the love relationship (.833). Sex is important, and it is an essential part of any intimate, love relationship.

Factor 5: Love grounded with secure foundations. "Love is defined as an intense feeling of affection" (.649), "Have you experienced natural parent-child love?" (.756), and "Do you love your parents?" (.740). Love has its basis in family members, such as parents and children. This type of love can presumably be extended to other significant people.

Factor 6: Love for one's fellow human beings. "Have you ever experienced agape love?" (.755) and "Is it likely one would experience love for a friend (philia)?" (.772). The capacity to love friends, and members of one's community.

Factor 7: Two people's love as destiny. "Do you believe in love at first sight?" (.727) and "Do soul mates exist?" (.721). The idea that love between two people is destined, even if they have never met each other before.

Factor 8: There is nothing special about love, but the rules need to be followed. "Can I have an affair and still love my wife...?" (-.469) and "Love is important to me as a person" (-.459).

Love is not important, but infidelity can destroy it.

Factor 9: If you love yourself, you don't fall in love with the first person you meet. "How long does it take to fall in love?" (.899) and "Do you love yourself (philautia)?" (.421). Love starts by loving yourself. 
And if you love yourself, then you do not need to quickly fall in love with someone else.

Factor 10. Nothing lasts forever, but good sex helps prolong things. "Would you leave your partner today for a better love relationship...?" (.803) and "Pragma love (between friends) endures" (-.427). The love between friends is not something that endures, and if the love side of a relationship is not working out, one should move one (See Table A5 below).

TABLE A5: Rotated component matrix, for the 10 factors. Loadings of .4 or greater are included.

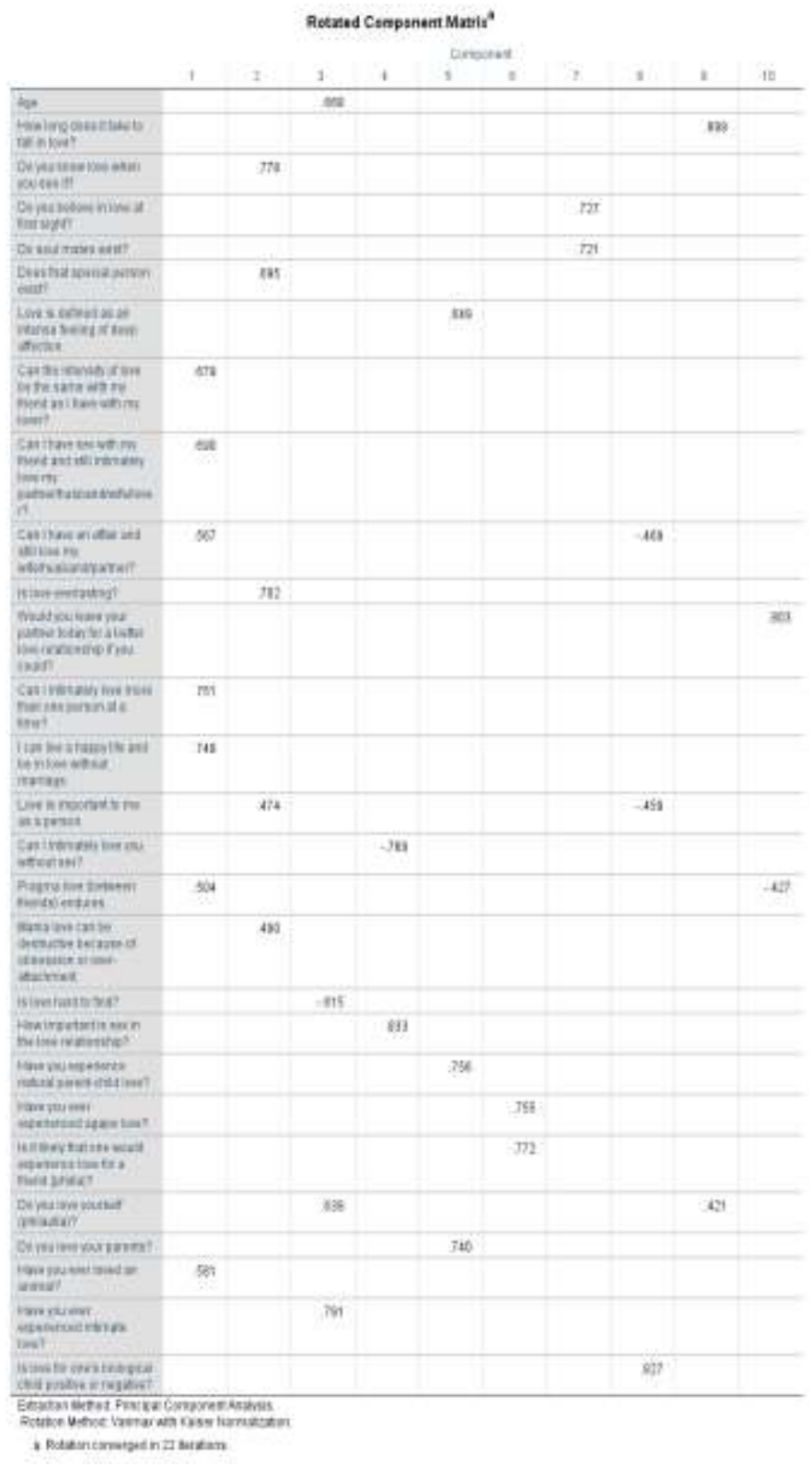

\section{DISCUSSION}

The study aimed to look at the relationship between different types of love, using a sample of young adults, aged between 18 and 35. The participants completed a survey, which included 29 items that gauged their attitudes to various approaches to love. The results showed numerous correlations between the items, and a factor analysis indicated there were ten factors. These factors pointed to different concepts of love, for example love without limits, love of one's friends, and the importance of sex.

The questionnaire included demographic questions, and there was evidence that demographics was influencing the results. Although participants were no older than 35, age differences seemed to influence participants' responses.
Age had a positive correlation with "Do you know love when you see it?", "Is love everlasting?", "Love is important to me as a person", "Have you experienced natural parentchild love?", "Do you love yourself (philautia)?”, "Do you love your parents?", and "Have you ever experienced intimate love?". The responses to some of these items may reflect life cycle progression. As people grow older, they may be more likely to have positive self-regard. They will also be more likely to have experienced intimate love and to have had children.

Gender and race also have an impact. Women had higher mean scores on the items "Love is important to me as a person", "Pragma love (between friends) endures", "Mania love can be destructive...", and "Is love hard to find". These results indicate that women may be more cautious than men when it comes to love. There is a greater respect for the love between friends, and a belief that love is not just hard to find but is also dangerous. In the case of race, the sample was overwhelmingly white $(72.5 \%)$, and it is difficult to draw conclusions about the differences between races. The item "'Can I have sex with my friend and still intimately love my partner/husband/wife/lover?" certainly had higher mean responses from Asians and Hispanics, but this may be a sampling rather than a demographic issue.

One of the purposes of looking at the correlations between items is to identify clusters. An example of a cluster is the one surrounding "Do you know love when you see it?". At the $p<.01$ level, this had correlations with "Does that special person exist?", "Is love everlasting?", and "Do you love yourself?". This cluster (see Figure A1 below) is about love being special and unique, as something that once found never ends. There is also a suggestion that if someone wants to be confident that such love exists, they also need to love themselves. Or put another way, to find true love, one first has to love oneself.

Figure A1. The correlations (Spearman's $\rho$ ) between the items "Do you know love when you see it?", "Does that special person exist?", "Is love everlasting?", and "Do you love yourself (philautia)?"

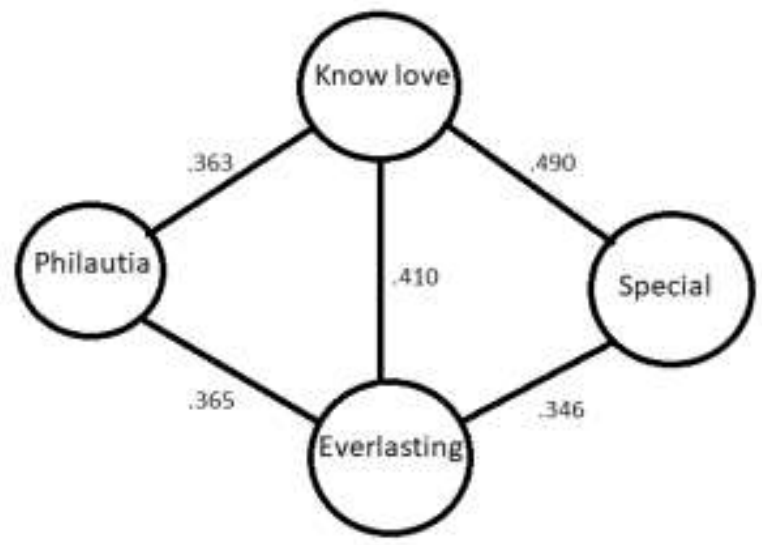

Another way of identifying clusters is to use factor analysis. This technique has certain assumptions, for example sampling adequacy, which the data does not conform to. Nonetheless, the study included a factor analysis. It yielded ten factors with eigenvalues of greater than one, and in a broad sense they conformed to the expected types of love. Factor 2, "Love is an ideal, enduring, and healthy state between two people", had a similar structure to the cluster just discussed, with "Do you know love when you see it?", "Does that special person exist?", and "Is love everlasting?" having high loadings on it. "Mania love is destructive..." also loaded onto it, and this suggests that the love envisioned by this factor is not obsessive or pathological. 
Or it might indicate that people who conceptualize an ideal love are aware of the kinds of love that they do not want.

When looking at factor analysis, it is worth considering factors that have unexpectedly high loadings. Factor 1 , "Love has no bounds", appeared to be about promiscuity, with relatively high loadings from "Can I have sex with my friend and still intimately love my partner...?" and "Can I have an affair and still love my wife...?" Yet it included "Pragma love (between friends) endures" and "Have you ever loved an animal?". These two items indicate a diversity of ways in which love can be expressed, and it might be that those scoring highly on this factor have an eclectic view of love and its possibilities.

The study had serious limitations. The items covered a wide range of concepts, and in many cases their wording was too long, or they were focused on more than once concept. For example, "I can live a happy life and be in love without marriage". A study with such variability would have benefited from more participants, especially in terms of factor analysis. On the other hand, if it had been known that there would only have been 51 participants, then the range of items should perhaps have been reduced. The issue of reliability is also important. Cronbach's alpha was .55 , which is too low - the usual minimum is around 0.7. Not only did the items lack internal consistency, but the results may have been unstable. The addition or subtraction of a few items, or a few participants, could have had a substantial influence on the results.

Another issue with the items was that some of them were related to personal circumstances. The questions about parents, animals, and children may have been dependent on whether participants had experience of these aspects of family and domestic life. They would not necessarily reflect on stable psychological traits. Age is also an important and changing measure of circumstance, and it could have acted as a confounding variable. Someone who is 18 is less likely to have experienced intimate love and parenting than someone who is 35 .

A future study would need a set of items that were more uniform, and which had a single concept. It is probably best to avoid mentioning technical words such as agape and pragma in the item wording. If one intends to measure the full range of love, then the sample size should be increased. Otherwise, a future study should restrict itself to two or three variations of love. Nonetheless, the present study has produced valuable material, which can form a useful basis for a follow-up investigation.

\section{REFERENCES}

[1] Burton, N. (2016, June 25). These are the seven types of love. Psychology Today, p. 1.

[2] Kaladharan, A. (2017). Top 10 Different Kinds of Love That You See in Life. Retrieved from Listovative.com: https://listovative.com/top-10-different-kinds-oflove-that-you-see-in-life/

[3] Kim, J. \&. (2004). Love types and subjective wellbeing A cross-cultural study. Social behavior and personality, 173-182.

[4] Morgan, C. (2020). Learn the Different Types of Love (and Better Understand Your Partner). Retrieved from Lifehack:

https://www.lifehack.org/articles/communication/ta ke-the-word-cant-out-of-your-vocabulary.html

[5] Neto, F. \& Wilks, D.C. (2017). Compassionate love for a romantic partner across the adult life span. Europe's Journal of Psychology, 606-617.

[6] Princess, B. (2010). The social psychology of love and attraction. McNair Scholars Journal, Vol. 14. Issue 1, 5-11.

[7] Raffagnino, R. \& Puddu, L. (2018). Love styles in Couple Relationships: A literature review. Open Journal of Social Science, 307-330.

[8] Smith, T. (2019, November 19). What are the 7 types of love? Retrieved from e Counselling.com: https://www.e-counseling.com/relationships/whatare-the-7-types-of-love/ 